\title{
Characterization of Some Efficient Cellulase Producing Bacteria Isolated from Pulp and Paper Mill Effluent Contaminated Soil
}

\author{
Kondakindi Venkateswar Reddy ${ }^{1}{ }^{*}$, Tatiparti Vijayalashmi ${ }^{1}$, Pabbati Ranjit ${ }^{1}$, Maddela \\ Naga Raju². \\ ${ }^{1}$ Jawaharlal Nehru Technological University - Center for Environment, Hyderabad, Telangana, India; \\ ${ }^{2}$ Universidad Estatal Amazonica - Department of Life Science Puyo, Pastaza, Ecuador.
}

\begin{abstract}
The wide variety of bacteria in the environment permits screening for more efficient cellulases to help overcome current challenges in biofuels production. This study focuses on the isolation of efficient cellulase producing bacteria found in pulp and paper mill effluent contaminated soil which can be considered for use in large scale biorefining. Four different bacterial strains were isolated and screened for cellulase production by using CMC agar medium. All isolates showed cellulase activity these strains were further characterized by morphological, physiological, biochemical and 16S rRNA gene analyses. These isolates were identified as two Bacillus subtilis sub sps, Bacillus mojavensis and Bacillus cereus.
\end{abstract}

Key words: CMC Agar, Cellulolytic Bacteria, Molecular identification, 16S rRNA, cellulolytic activity.

*Author for correspondence: 


\section{INTRODUCTION}

Increasing demand and rising cost of fossil fuels as well as a concern for global climate change have shifted global efforts to utilize renewable resources for the production of a greener energy replacement(1).Lignocellulosic biomass (plant biomass), is a renewable abundant and inexpensive resource for the bioconversion to biofuels and bioproducts.Plant dry weight includes 35-50\% cellulose ,20$35 \%$ Hemicellulose , and 5-30\% lignin (2) known as abundant, there are a great many sources to derive lignocellulosic biomass from such as municipal waste, agricultural residues, forestry or pulp and paper excesses, and energy crops(i.e. switch grass) (3). Cellulose is a linear polymer of glucose linked through $\beta,-1,4-$ glycosidic linkages. These linkages are hydrolyzed by cellulase which also plays a role in recycling the polysaccharides. Cellulose consists of various enzymes such as endoglucanase (EC 3.2.1.4), exoglucanase(EC 3.2.1.74), and $\beta$ - glucosidase(EC 3.2.1.21)(4).The microorganisms identified thus far to be involved in production of cellulases and related enzymes mainly include bacteria, some fungi and actinomycetes(5).Cellulolytic organisms of fungal origin produce cellulase used in food, animal feed,textiles,fuel,the chemical industry etc(6,7).However because of slow growth of fungi, cellulase production costs are high for these processes. In contrast, a bacterial culture is simple, grows rapidly, and has ashort generation time, and other beneficial characteristics: thus, it has good potential applicability (8).

In this study, several efficient cellulase producing microorganisms were isolated from different pulp and paper mill effluent contaminated soil. The purpose was to identify and characterize those isolates displaying the greatest cellulase activity for the possible use in the large scale biorefining.

\section{MATERIALS AND METHODS}

\section{Isolation and screening of cellulolytic microbes}

Soil samples were collected from pulp and paper mill effluent polluted area. This soil sample served as source of inoculam.Traditional serial dilution \& agar plating method was used for the isolation of cellulolytic bacteria. The medium used for cellulolytic bacteria contains CMC $1.88 \mathrm{~g}$, sodium citrate $0.5 \mathrm{~g}, \mathrm{~K}_{2} \mathrm{HPO}_{4} 7.0 \mathrm{~g}$, $\mathrm{KH}_{2} \mathrm{PO}_{4} 2.0 \mathrm{~g},\left(\mathrm{NH}_{4}\right)_{2} \mathrm{SO}_{4} 1.0 \mathrm{~g}, \mathrm{MgSO}_{4} .7 \mathrm{H}_{2} 00.1 \mathrm{~g}$, Agar $10 \mathrm{~g}$, Congo red $0.20 \mathrm{~g}, \mathrm{P}^{\mathrm{H}}$ 7.0, Distilled water 1 lit. The plates were incubated for $2-3$ days at $37^{\circ} \mathrm{C}$ and observed for clear zone around the colony. To visualize the hydrolysis zone the plates were flooded with an aqueous solution of $1 \%$ Congo red for 15 min (9).To visualize clear zone formed by cellulase positive strains the plates were destained using $1 \mathrm{M}$ Nacl solution. The bacterial colonies having clear zone were selected for identification and cellulase production. Further bacterial strains were purified by repeated streaking. The purified colonies were preserved at $4^{0} \mathrm{C}$.

\section{Identification of Bacteria}

For the identification of strain of interest cultural characteristics, morphological characteristics and biochemical test were conducted and identified on the basis of characters as given in Bergey's manual of systematic Bacteriology (10). The parameters investigated included Indole test, Methyl red test, Voges Proskauer test, Citrate utilization test, Catalase test, Oxidase test, Gelatin test, Motility test, Amylase test, Nitrate reduction test, Carbohydrate fermentation test by standard methods. The various media was prepared in sterile distilled water and $\mathrm{pH}$ was adjusted accordingly. 


\section{Cellulolytic activity assay}

Cellulolytic activity was measured as a diameter of clear zone after the CMC plate was poured by $1 \%$ Congored. Cellulolytic index was calculated using formula as follows (11):

Cellulolytic index $=\quad$ (Diameter of zone - Diameter of Bacterial colony) Diameter of Bacterial colony

\section{Molecular Identification of Bacterial isolates}

DNA was extracted and purified by using a Qiagen genomic DNA extraction kit. The complete length of the 16S rRNA gene sequence was obtained by sequencing with primers, F'-27 (5'- GTTTGATCCTGGCTCAG-3'), and R'-1489 (5'TACCTTGTTACGACTTCA-3') (Positions 11-27 and 1489-1506 (for F'-27 and R'-1489 respectively). 16S rRNA gene sequencing was performed on a 3130xl Applied Biosystems ABI prism automated DNA sequencer.16S rRNA gene sequences of the strains were identified by BLAST search analysis on EzTaxon - e server (12).

\section{Bioinformatics analysis and phylogenetic tree construction}

The data of 16S rRNA gene sequences were identified using BLAST-N search program in national center for Biotechnology information (http://www.ncbi.nlm.nih.gov). The 16S rRNA gene sequences were aligned and Phylogenetic tree was constructed using MEGA6.0 Software with neighbor - joining method at 1000X boot straps (13).

\section{RESULT AND DISCUSSION}

\section{Isolation and screening of cellulase producing Bacterial Isolates}

Cellulose is the main building blocks of plants and have major fraction of organic carbon in soil. Microorganisms, which live in soil, are accountable for recycling of this organic carbon to the Environment (14).Degradation of cellulosic materials is a complex process and requires participation of microbial cellulolytic enzymes. Habitats where these substrates are present are the best sources for isolation of cellulolytic microorganisms (15). Several microorganisms have been discovered for decades which have capacity to convert cellulose in to simple sugars (16) but need for newly isolated cellulose degrading microorganisms still continues (17).

The cellulase producing bacteria were isolated from different samples by serial dilution method and spread plating on CMC agar. CMC agar is a selective media and selectively supports the growth of the cellulolytic organisms because cellulase producing organisms can only utilize cellulose as the carbon source. The screening of the cellulolytic bacterial isolates was performed based on the diameter of clearing zone surrounding the colony on the CMC Agar medium. The appearance of the clear zone around the colony after the addition of Congored solution was strong evidence that the bacteria produced cellulase in order to degrade cellulose.

\section{Morphological and Biochemical characteristics of cellulolytic bacterial isolates} Four cellulolytic bacteria were isolated from paper and pulp industry effluent contaminated soil. All bacterial isolates are Gram positive, rod shaped, motile and endo spore forming bacteria. They are all showed positive reactions for Catalase, oxidase, Gelatinase, Amylase, Voges proskauer, citrate utilization test and Negative reactions for indole, methyl red test. All isolates ferment glucose, fructose \& sucrose but not mannitol \& lactose. 


\section{Cellulolytic activity of bacterial isolates}

Cellulolytic activity of bacterial isolates was based on clear zone of degraded CMC area around the colony. Cellulolytic activity test showed that isolate I (JCEN I) \&isolate IV (RW) has the largest cellulolytic index (2.5 \& 2.0) isolate II (JCEN2) \&isolate III (JCEN3) has the smallest cellulolytic index $(0.85 \& 0.75)$ respectively. Based on cellulolytic index and growth isolate I and IV were potential isolates.

Table 1- cellulolytic index of isolated cellulolytic bacteria.

\begin{tabular}{cccc}
\hline Isolate & Diameter of colony $(\mathbf{m m})$ & Diameter of cellulolytic zone $(\mathbf{m m})$ & Cellulolytic index \\
\hline JCEN 1 & 8.0 & 28 & 2.5 \\
JCEN2 & 3.5 & 6.5 & 0.85 \\
JCEN3 & 6.0 & 10.5 & 0.75 \\
RW & 8.0 & 24 & 2.0 \\
\hline
\end{tabular}

Molecular characterization based on 16S rRNA gene analysis

The GenBank/EMBL/DDBJ accession numbers for the 16S rRNA gene sequences of strains are JCEN1, JCEN2, JCEN3\&RW.HF951564, HF951565, HF951566 \& HG421740 respectively.

DNA was extracted and purified by using a Qiagen genomic DNA extraction kit. The complete length of the 16S rRNA gene sequence was obtained by sequencing with primers, F'-27 (5'- GTTTGATCCTGGCTCAG-3'), and R'-1489 (5'TACCTTGTTACGACTTCA-3') (Positions 11-27 and 1489-1506 (for F'-27 and R'-1489 respectively). 16S rRNA gene sequencing was performed on a 3130xl Applied Biosystems ABI prism automated DNA sequencer.16S rRNA gene sequences of the strains were identified by BLAST search analysis on EzTaxon-e server. Strains JCEN1\&JCEN2 were sequence similarity with Bacillus subtilis subsps (99.6\%\&99\%), JCEN3 sequence similarity with Bacillus mojavensis (99\%) \& Strain RW was sequence similarity with Bacillus cereus (98.47\%).

Phylogenetic analysis of 16S rRNA gene sequences

Phylogenetic analysis was done using sequences targeting from 16S rRNA gene sequence of bacteria. The data of $16 \mathrm{~S}$ rRNA gene sequences were identified using BLAST-N search program in national center for biotechnology information (http;//www.ncbi.nlm.nih.gov).The 16S rRNA gene sequences were aligned and Phylogenetic tree was constructed using MEGA 6.0 software. 


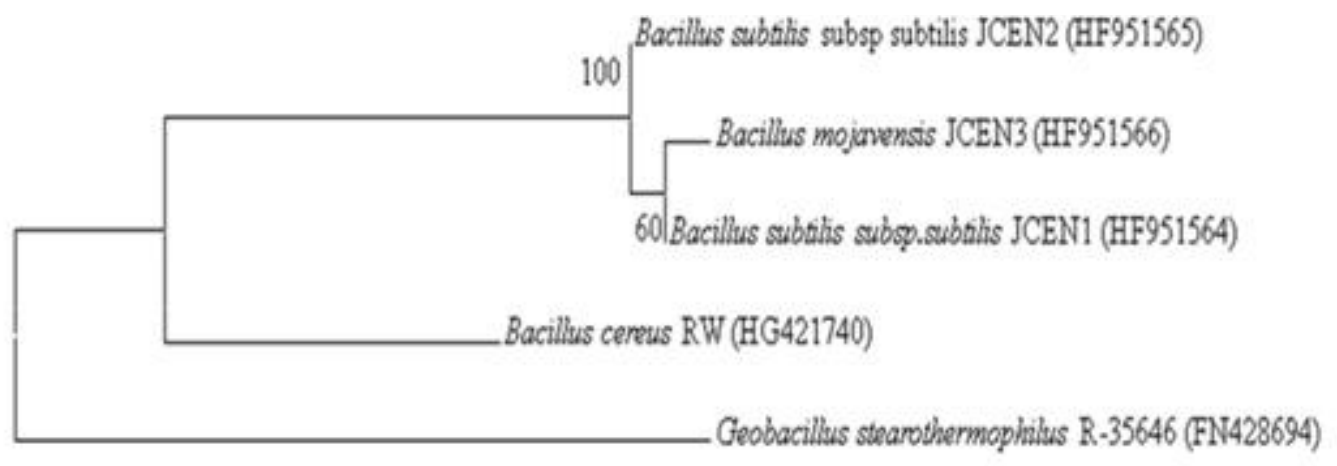

001

Fig 1- Neighbor-joining tree based on 16S rRNA gene sequences showing phylogenetic relationships between strains JCEN2, JCEN3, JCEN1, RW and R-35646. The tree was computed with MEGA- 6 and rooted by using Geobacillus stearothermophilus as the out-group. The GenBank accession numbers for 16S rRNA gene sequences are shown in parentheses. Bootstrap percentages refer to $\mathrm{NJ}$ analysis. Bar, 0.01 nucleotide substitution per position.

\section{CONCLUSION}

According to this study, our isolation screening and identification methods were quick and efficient for allowing us to identify several good cellulase producing bacteria from a wide variety of samples. Moreover, we were able to distinguish the isolates displaying the greatest cellulase activity for future study. Finding naturally occurring cellulase producing bacteria from the environment is important in the field of biorefining to help overcome costly hurdles in the biorefining process. All of our cellulase positive isolates may be an integral part of future work to develop good cellulases or produce efficient cellulase producing systems such as microbial consortia which can be used for industry. Isolation and characterization may provide a good starting point for the discovery of such beneficial enzymes.

\section{ACKNOWLEDGEMENTS}

Authors are thankful to the staff of pulp and paper mill, A.P, INDIA. For their timely help and encouragement throughout this study.

\section{REFERENCES}

1. Schneider SH. The green house effect: Science and policy. 1989; 243:771-781.

2. Lynd LR, Wyman CE Gerngross TU.Biocommodity engineering.Biotechnol prog 1999;15:777-793.

3. Green N. Growing energy. How biofuels can helpend Americas oil dependence. Nat res def council rep.2004: p.1-86.

4. Morana A,Maurelli L, Ionota E,La cara F, Rossi M.. Cellulases from fungi \&bacteria and their biotechnological applications.In:Golan AE (ed) cellulase: Types \& action, mechanism \& uses. Newyork (US):Nova science publisher,Inc. 2011.p. 1-79.

5. Beguin $\mathrm{p}$, Aubert JP. The biological degradation of cellulose.FEMS Microbiol rev 1994; 13:25-58.

6. Singhania RR,Sukumaran RK,Patel AK,Larroche C, Pandey A. Advancement \&comparative profiles in the production technologies using solid state and submerged fermentation for microbial cellulases. Enzyme microb Technol 2010: 46:541-549.

7. Karmakar M,Ray RR.Current trends in research and application of microbial cellulases. Res J Microbiol 2011; 6:41-53. 
8. Westers L,Westers H,Quax WJ. Bacillus subtilis as cell factory for pharmaceutical proteins: Abiotechnological approach to optimize the host organisms. Biochem Biophys Acta Mol cell Res 2004; 1694: 299-310.

9. BRANDER, J.R., GILLINGS, M, K.M.H NEVALAINEN.. Qualitative assessment of hydrolytic activities in Antarctic micro fungi grown at different temperatures on solid media. World. J. microbial. Biotechnol, 1999; 15: 131-132.

10. BERGEY, D. Manual of determinative bacteriology, American - for microbiology, Williams and willkins co. publishers, Baltimore, USA, 1957; VII edition

11. Ferbiyanto,A., Rusmana, I., Raffiudin, R.,Charectarization and identification of cellulolytic bacteria from gut of worker macrotermes gilvus. Hayati journal of life sciences 2016. P. 1-4

12. Kim, O.S., Cho, Y.J., Lee, K., Yoon, S.H., Kim, M., Na, H., Park, S.C., Jeon, Y.S., Lee, J.H., Yi, H., Won, S., Chun, J. Introducing EzTaxon-e: a prokaryotic 16S rRNA Gene sequence database with phylotypes that represent uncultured species. Int J Syst Evol Microbiol 2012; 62: 716-721

13. Tamura,K., Stecher, G., Peterson, D., Filipski, A.,\&Kumar.,SMEGA 6:Molecular Evolutionary genetic analysis(MEGA)Version 6. Mol Biol Evol 2013; 30: 2725-2729.

14. Wang CM, Shyu CL, Hosp,Chiou SH. Charaeterization of a novel thermophilic, cellulose degrading bacterium Paeni bacillus sp. strain B39. Lett App/Microbiol 2008:47(1):46-53.

15. Das A, Bhattacharya S, Murali L. Production of cellulase from a thermophilic Bacillus sp. isolated from Cow dung.American -Eurasian J Agric Environ Sci 2010: 8(6): 685691.

16. Perez. J., Munoz-Dorado, J., Dela Rubia J., Marinez, J.Biodegradation and biological treatments of cellulose, hemicelluloses and lignin an overview. International microbiology 2002; 5: 53-63

17. Nirajane AJ.Madhou P, Stevenson TW.The effect of carbohydrates sources on the production of cellulase by phlebiagigantean. Enzyme Microb Technol 2007; 40:14641468. 